\title{
Feed Intake, Milk Yield and Composition, and Profitability of Horro Cows Fed Rhodes Grass Hay Supplemented with Ficus sur (Cv. Forssk) Fruits
}

\author{
Diribe Kumsa $^{1^{*}}$, Mitiku Eshetu $^{2}$ and Diriba Diba ${ }^{1}$ \\ ${ }^{1}$ Department of Animal Sciences, Wollega University, P.O. Box: 395, Nekemte, Ethiopia \\ ${ }^{2}$ School of Animal and Range Sciences, Haramaya University, P.O.Box: 138, Dire Dawa, Ethiopia
}

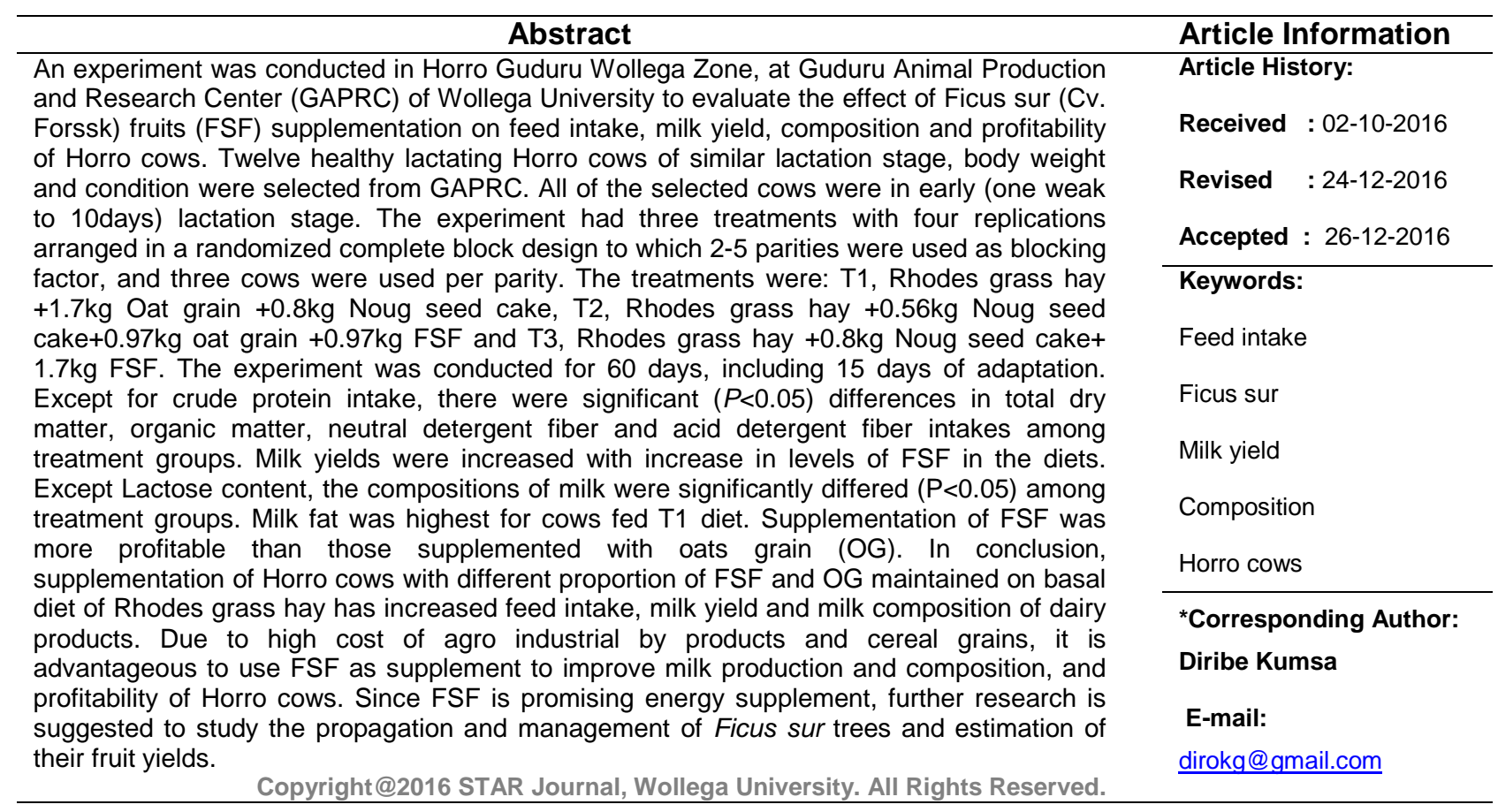

\section{INTRODUCTION}

Ethiopia has diverse agro-ecological zones suitable for livestock production and for growing diverse types of food and fodder crops. The country is believed to have the largest livestock population than other countries in Africa (CSA, 2013). Livestock in Ethiopia contribute considerably to the national economy and the livelihood of the citizens. The subsector contributes 15 to $17 \%$ of national gross domestic product (GDP) and 35 to $49 \%$ of agricultural GDP and 37 to $87 \%$ of the household incomes (Behnke and Metaferia, 2011). Livestock are integral components of the Ethiopian agricultural farming systems, and perform multiple functions at different levels. Livestock are important source of food (meat and milk), cash income, transport services, traction power and manure as fertilizer for crop production for smallholder farmers. They have also social and cultural values among producers. Livestock provides wide and year-round employment opportunities in urban and rural Ethiopia. Cash income from livestock production is important particularly for women, as is also common in many other developing countries. Despite the significant roles of livestock in the country, animal productivity is low mainly due to inadequate feed (Alemayehu, 2006).

Dairy production, among the sector of livestock production, plays an important role in Ethiopia serving as sources of food and income. Irrespective of their number and importance; however, the productivity of dairy animals in Ethiopia is usually low and incompatible to the high population of the species. The national average milk yield per cow per day is 1.54 liters for indigenous cows, and per capita/year milk consumption in the country is about 16 $\mathrm{kg} / \mathrm{year}$, which is much lower than African and world per capita average of $27 \mathrm{~kg} / \mathrm{year}$ and $100 \mathrm{~kg} / \mathrm{year}$, respectively (Belay et al., 2012). This low level of productivity of Ethiopian cattle breeds could be attributed to animal diseases, lack of proper management, poor 


\section{Diribe Kumsa et al.,}

nutrition and poor genetic potential. However, nutrition exerts the largest influence (Adugna, 2007).

Currently, feed is the main constraint limiting livestock productivity in Ethiopia (Alemayehu, 2006). Livestock feed in the country is derived mainly from unimproved natural pasture and crop residues. These feed resources contain high fiber and low digestibility which does not support optimum livestock production (Adugna, 2008). Besides, the availability of tropical feed resources follows seasonal dynamics of rainfall and there is severe feed shortage during the dry periods. Shortage and deterioration of feed quality also mostly happens in dry season of the year (Demissu et al., 2015). Consequently, the supply of protein and energy is marginal.

In this regard, most of the rural areas in Ethiopia receive a dry period of about six months or more. In this areas crop residues and aftermaths of poor nutritional quality are the major sources of feed for ruminants like dairy cows (Adugna, 2007). It has been observed that the milk production by smallholder dairy farmers during the dry season is significantly reduced (Pandey and Voskui, 2011). In tropical climate improved grasses such as Rhodes, having C4 grass characteristics, are not enough to optimize milk yield of cows without supplementation with concentrate diets.

Under smallholder farm conditions of Ethiopia, different green herbages such as leguminous trees and herbaceous legumes grown on farm can be used as protein supplements whereas energy source concentrate supplements are scarce in these production systems (Diriba et al., 2014). This is due to the fact that most of the energy rich supplements are costly cereal grains that are used as staple food by farmers in the tropics. Other sources are agro-industrial by products that rural households cannot easily access due to inadequacy, localized availability and very high cost of purchase and transport. Supplementation of low quality feeds with other feed resources that contain better nutrients is an alternative strategy to improve the utilization of low quality feeds and thereby enhance livestock production (Diriba et al., 2014).

One of such feeds could be Ficus sur fruit (FSF), which is cheaper and easily accessible than concentrates. FSF which is widely distributed in most of the regional states in Ethiopia may be used to fill the gap of energy concentrate scarcity during dry season. Because the fruits of such tree mature during the dry periods (December to May) of feed scarcity and all livestock classes used to consume normally and their body condition usually improves. However, no documented information is available, so far, on supplementary value of FSF for dairy animals. The objective of this study, therefore, was to investigate the effect of FSF supplementation on feed intake, milk yield and composition, profitability of Horro cows.

\section{MATERIALS AND METHODS}

\section{Description of the Study Area}

The study was conducted in Horro-Guduru Wollega zone, at Guduru Animal Production and Research Center of Wollega University (the former Horro Guduru Cattle Ranch). The Research Center is located at about $300 \mathrm{~km}$ west of Addis Ababa. The geographical coordinates of the study area is $09^{\circ} 29^{\prime} \mathrm{N}$ and $37^{\circ} 26^{\prime} \mathrm{E}$. The altitude of the
Sci. Technol. Arts Res. J., Jan-March 2016, 5(1): 39-45

center is approximately 2296 m.a.s.l. The area has one rainy season extending from late March to mid-October (Bezuayehu, 2006). The monthly mean temperature varies between $14.9^{\circ} \mathrm{C}$ to $17.5^{\circ} \mathrm{C}$ and annual rainfall ranging from $1000-2400 \mathrm{~mm}$. Mixed crop-livestock agriculture is the dominant production system in the area. Cattle, sheep, goats, equines, poultry and honey bee production are the major animal species produced in the area ( Demissu et al., 2015) while maize (Zea mays), sorghum (Sorghum bicolor), teff (Eragrostis teff), wheat and other cereals and pulses are the main crops growing in the study area.

\section{Experimental Animals and Management}

Twelve healthy lactating Horro cows of similar lactation stage and body condition were selected from Horro Guduru Animal Production and Research Center. All of the selected cows were from early lactation stage of one weak. Prior to the start of the experiment, all the cows were weighed and drenched with broad-spectrum antihelminthics (Albendazole 500mg). Continuous follow up on the health care of the animals was made throughout the experiment. The cows were maintained and stall-fed individually in a well-ventilated and concrete floor barn.

\section{Experimental Feed Preparation}

The late matured and naturally dried Ficus sur fruits (FSF) dropped from the tree were collected by casual workers. After collection, the fruits were further sun dried, not finely ground but crushed to smaller parts and used for the experiment.

Oat grain was purchased from the communities around the study area and noug seed cake from nearby oil processing factories. Rhodes grass hay was used as a basal diet throughout the experimental period. The feed supplement was weighed and offered in a separate feed trough twice a day at 8:00 AM and 6:00 PM. The basal diet was fed ad libitum and adjusted up to $20 \%$ refusal level. Feed refusals were collected and weighed before the next feeding. Samples of feed offer and refusals were separately taken and bulked over 45 days for feed intake analysis. Feed intake was calculated as difference of the quantity of feed offered and feed refused. The animals had free access to clean water throughout the experimental periods.

\section{Experimental Design and Treatments Treatments}

The dietary treatments used in the feeding trial were described as follows: Rhodes grass hay was offered ad libitum at $20 \%$ refusal rate plus Noug seed cake (NSC) supplement. The other two treatments received Rhodes grass hay supplemented ad libitum, with different proportions of FSF and oats grain (OG) in addition to adjusted provision of NSC. The gram amount of Noug seed cake (NSC), as protein supplement, varied based on the nitrogen content of energy diets, FSF and OG, to keep all the treatments at iso-nitrogenous level.

The average body weight of Horro cows used in the experiment was about $250 \mathrm{~kg}$. Therefore, the amount of daily ration supplied was calculated as $2.5 \%$ of body weight, which is $6.25 \mathrm{~kg}$. For a normal dairy cow, dry matter consumed within 24 hours should be $2.5-3 \%$ of its body weight (Mc Donald et al.,1995). The proportion of concentrate supplement to roughage was $40 \%$ of the $6.25 \mathrm{~kg}$ which was $2.5 \mathrm{~kg}$ per day and the rest was Rhodes 


\section{Diribe Kumsa et al.,}

grass hay. The treatment proportions for FSF and OG was calculated from the daily total concentrate level $(2.5 \mathrm{~kg})$ in the ration.

Table 1: List of dietary treatments used in the experiment

\begin{tabular}{ccccc}
\hline No. & Diets & T1 & T2 & T3 \\
\hline 1 & NSC & $0.80 \mathrm{~kg}$ & $0.56 \mathrm{~kg}$ & $0.80 \mathrm{~kg}$ \\
2 & FSF & 0.00 & $0.97 \mathrm{~kg}$ & $1.70 \mathrm{~kg}$ \\
3 & OG & $1.7 \mathrm{~kg}$ & $0.97 \mathrm{~kg}$ & 0.00 \\
4 & RGH & Ad libitum & Ad libitum & Ad libitum
\end{tabular}

$\mathrm{OG}=$ Oat grain; FSF=Ficus sur fruit; NSC=Noug seed cake $\mathrm{RGH}=$ Rhodes grass hay; $\mathrm{T}=$ treatment

\section{Experimental Design}

Three dietary treatments were randomly assigned to four cows which were arranged in Randomized Complete Block Design (RCBD). The lactating cows of similar lactation stage, early stage of lactation, and similar body weight were selected from the total lactating dairy herd. Two to five parity, and three animals per parity were used as blocking factor. The experiment was lasted for 60 days including 15 days of adaptation. Number of animals used per treatment (four) in this experiment was limited in view of statistical standards, because of shortage of feeds' budget to maintain more number of cows.

\section{Experimental Measurements Chemical Analysis of Feeds}

Chemical analysis of the feed samples was done at Holeta Agricultural Research Center. The samples were dried in an oven at $105^{\circ} \mathrm{C}$ overnight in a forced draft oven to determine the DM contents of the feed. The other part of feed samples dried at $65^{\circ} \mathrm{C}$ was ground to pass through $1 \mathrm{~mm}$ screen size for chemical analysis. Neutral Detergent Fiber (NDF), Acid Detergent Fiber (ADF) and Acid Detergent Lignin (ADL) were determined following the procedures of Van Soest and Roberson (1985). The ash and Nitrogen $(\mathrm{N})$ content was analyzed according to the procedures described by AOAC (2000). Nitrogen was analyzed by Kjeldhal technique and $\mathrm{CP}$ was calculated as $\mathrm{N} \times 6.25$

\section{Feed Intake}

A ration was prepared and fed to each animal twice daily. Data on feed offered and feed refused were collected to determine feed intake throughout the experimental days. Samples of feed offered and feed refusals of each animal were collected on daily basis, and bulked over the experimental period for each treatment. At end of the feeding experiment, sub samples were taken for further chemical analysis. Feed intake was calculated as the difference between the quantity of feed offered and feed refused from each animal per day.

\section{Milk Yield}

All cows were hand milked twice a day regularly at about 7:00 AM in the morning and 5:00 PM in the afternoon. The morning and evening milk yield was recorded on daily basis. The milk consumed by the calf was calculated by taking the weight of the calf before and after suckling. This helps us control the error on milk yield due to variation in suckling ability of calves of cows under different feeds treatment. Milk yield from each cow is equal to milked milk plus suckled milk. Milk yield from each cow was measured by using graduated measuring cylinder and then recorded on the datasheet.
Sci. Technol. Arts Res. J., Jan-March 2016, 5(1): 39-45

\section{Milk Composition Analysis}

Samples of milk were collected for the analysis of chemical compositions at Holeta research center dairy laboratory. The milk samples were kept in an ice box and transported to the Holeta dairy laboratory. Representative sample was taken to determine fat, solids not-fat (SNF), lactose and protein content of the milk.

\section{Total Protein}

Formaldehyde titration method was used to determine the total protein content. Ten $\mathrm{ml}$ of milk was added into a beaker. Then, $0.5 \mathrm{ml}$ of 0.5 percent phenolphthalein indicator and $0.4 \mathrm{ml}$ of 0.4 percent Potassium Oxalate was added into the milk. Then, the sample was titrated with $0.1 \mathrm{~N}$ Sodium Hydroxide solution. The titration was continued until pink color becomes intense. Finally, the burette reading was recorded. The reading was multiplied by a factor 1.74 (Foley et al., 1974). Percent protein = Burette reading $\times 1.74$

\section{Milk Fat}

Gerber method was used to determine the milk fat content. Milk samples were kept at $37^{\circ} \mathrm{C}$ for 30 minutes in a water bath to maintain the milk to normal body temperature of the cow. Ten milliliter of concentrated sulphuric acid was pipetted into a butyrometer. Then 11 $\mathrm{ml}$ of milk was added using milk pipette into a butyrometer having the sulphuric acid, and then one millilitre of amyl alcohol was added. The butyrometer stopper was put on and the sample was shaken and inverted several times until all the milk was digested by the acid. Then the butyrometer was placed in a water bath at $65^{\circ} \mathrm{C}$ for five minutes. The sample was placed in a Gerber centrifuge for four minutes at $1100 \mathrm{rpm}$ (rotations per minute). Finally, the sample was placed in to water bath for 5 minutes at $65^{\circ} \mathrm{C}$ and fat percentage was read from the butyrometer (ILCA, 1988; Van den Berg, 1988). The average of duplicate readings was computed and recorded.

\section{Total Solids}

To determine the total solids, five grams of milk sample was placed in a pre-weighed and dried duplicate of crucibles. The samples were kept at $102^{\circ} \mathrm{C}$ in a hot air oven overnight. Then, the dried samples were taken out of the oven and placed in desiccators. Then the dry sample was weighed (O'Connor, 1994).

Total solids $=$

(Crucible weight +oven dry sample weight- Crucible weight) $\times 100$ Sample weight

\section{Solids- Not -Fat}

The solids not fat (SNF \%) was determined by subtracting the percent fat from total solids (O'Mahoney, 1988).

$$
S N F=(T S-\text { fat }) \times 100
$$

\section{Total Ash}

The total ash was determined gravimetrically by igniting the dried milk samples in a muffle furnace in which the temperature was slowly raised to $550^{\circ} \mathrm{C}$. The sample was ignited until carbon (black color) disappears or until the ash residue becomes white (Richardson, 1985).

$$
\text { Percentash }=(\underline{\text { Weight of residue }}) \times 100
$$
Weight of sample 
Diribe Kumsa et al.,

\section{Lactose}

Percent lactose was determined by subtracting the fat, protein and total ash percentages from the percentage of the total solids (O'Mahoney, 1988).

\section{Percent lactose $=$}

Percent total solids-(\%fat+ \% protein+ $\%$ total ash)

\section{Partial Budget Analysis}

Partial budget analysis was performed to evaluate the economic advantage of the different treatments by using the procedure of Upton (1979). The partial budget analysis involved the calculation of variable costs and benefits. The selling price of milk in each treatment was considered as total return (TR) in the analysis. For the calculation of the variable costs, the expenditures incurred on various feedstuffs were taken into consideration. The cost of the feeds was computed by multiplying the actual feed intake for the whole feeding period with the prevailing market price. The prevailing price of the feeds at the time of feed purchasing was recorded. Partial budget method measures profit or loss, which was the difference between gains and expenses for the proposed change and includes calculating net return (NR), i.e., the amount of money left when total variable costs (TVC) were subtracted from the total returns (TR):

$$
\mathrm{NR}=\mathrm{TR}-\mathrm{TVC}
$$

Total variable costs included the costs of all inputs that changed due to the change in production volume. The change in net return $(\Delta \mathrm{NI})$ was calculated by the difference between the change in total return $(\Delta T R)$ and the change in total variable cost $(\triangle T V C)$.

$$
\Delta \mathrm{NR}=\Delta \mathrm{TR}-\Delta \mathrm{TVC}
$$

The marginal rate of return (MRR) measures the increase in net income $(\Delta N R)$ associated with each additional unit of expenditure ( $\triangle T V C)$. This is expressed in percentage as:

$$
M R R=(\Delta N R / \Delta T V C) \times 100
$$

\section{Statistical Analysis}

The data on feed intake, milk yield, and composition was statistically analyzed by using the General Linear Model (GLM) procedure of statistical analysis system (SAS, 2008) software version 9.1.3 and means were separated by Duncan's Multiple Range Test (DMRT) at $\alpha=0.05$. The partial budget analysis was described using arithmetic approaches.

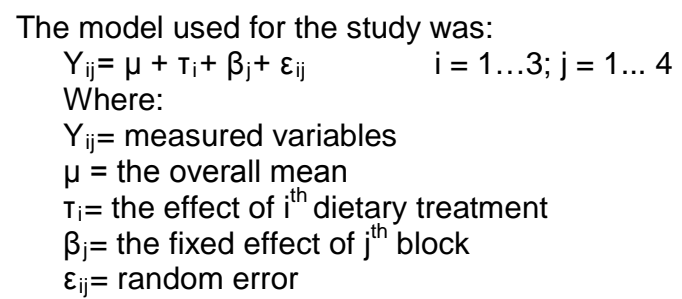

\section{RESULTS AND DISCUSSION}

\section{Feed Chemical Composition}

The result of the present study indicated that the dry matter (DM) content of FSF and OG were $93.90 \%$ and 90.68, respectively (Table 2$)$. The dry matter (DM) content of FSF $(93.9 \%)$ is higher than the DM $(87.3 \%)$ reported by Diriba et al (2014), and that of OG (90.675) is lower than
Sci. Technol. Arts Res. J., Jan-March 2016, 5(1): 39-45

DM content of FSF. Even though the fruits were collected from same area, the difference observed may be an attribute of weather variation from place to place that different levels of moisture could be removed from the fruits during drying. The CP content of FSF in this study was $7.4 \%$ which is comparable with the result $(7.07 \%)$ reported by Diriba et al (2014). The current result indicates FSF fulfills the minimum CP (7\%) requirement for microbial fermentation (Van Soest 1994), but cannot support optimum milk production unless supplemented. The NDF content of FSF was $32.7 \%$ which is in agreement with the report of Diriba et al (2014) who found $<45 \%$ NDF for FSF.

In this study, Oat grain (OG) has similar DM (90.68\%) value with 89 and $90.2 \%$ reported by Staton (2014) and Mesfin et al (2008), respectively. The CP content (6.1\%) of OG obtained in this study is lower than CP content (13\% and $8 \%$ ) reported by Staton (2014) and Mesfin et al (2008), respectively. Such variations may be due to differences in varieties or accessions of oat grains used by these different researchers. The CP content of OG was below that of FSF, and it was again below the minimum requirement of $(7 \%)$ for ruminant microbial fermentation, which needs supplementation. The NDF content of OG $(42.8 \%)$ obtained in this study is higher than the result (31\% and 38.2\%) reported by Staton (2014) and Mesfin et al (2008), respectively and that of FSF values. This may be due to variation in variety of the OGs used by them and what we used in the current experiment in the same case as its CP content. Smith et al. (2012) confirmed that cereal grains of different varieties or species could have different nutrient contents.

Table 2: Chemical compositions of experimental feeds

\begin{tabular}{lllllll}
\hline Feeds & $\begin{array}{l}\text { DM } \\
(\%)\end{array}$ & $\begin{array}{l}\text { Ash } \\
(\%)\end{array}$ & $\begin{array}{l}\text { CP } \\
(\%)\end{array}$ & $\begin{array}{l}\text { NDF } \\
(\%)\end{array}$ & $\begin{array}{l}\text { ADF } \\
(\%)\end{array}$ & $\begin{array}{l}\text { ADL } \\
(\%)\end{array}$ \\
\hline OG & 90.68 & 5.15 & 6.10 & 42.80 & 20.00 & 15.10 \\
FSF & 93.90 & 4.83 & 7.40 & 32.70 & 17.20 & 10.50 \\
NSC & 97.20 & 6.80 & 33.55 & 37.00 & 26.40 & 15.70 \\
RGH & 91.71 & 9.19 & 7.08 & 70.22 & 37.83 & 4.86 \\
\hline Refusal & & & & & & \\
RGH T1 & 96.35 & 5.33 & 1.24 & 80.20 & 50.50 & 8.00 \\
RGH T2 & 96.65 & 5.40 & 1.11 & 80.60 & 48.30 & 8.10 \\
RGH T3 & 94.93 & 4.98 & 1.02 & 75.60 & 50.20 & 11.30
\end{tabular}

$\overline{\mathrm{ADF}}=$ acid detergent fiber; $\mathrm{ADL}=$ acid detergent lignin; $\mathrm{CP}=$ crude protein; DM = dry matter; NDF = neutral detergent fiber; NSC=Noug seed cake; $\mathrm{RGH}=\mathrm{Rhode}$ grass hay; $\mathrm{T} 1=\mathrm{RGH}$ ad libtum $+1.7 \mathrm{~kg}$ OG $+0.8 \mathrm{~kg}$ NSC; T2 $=\mathrm{RGH}$ ad libtum $+0.56 \mathrm{~kg} \mathrm{NSC}+0.97 \mathrm{~kg} \mathrm{FSF}+$ $0.97 \mathrm{~kg} \mathrm{OG} ; \mathrm{T} 3=\mathrm{RGH}$ ad libtum $+0.8 \mathrm{~kg} \mathrm{NSC}+1.7 \mathrm{~kg}$ FSF

\section{Feed Intake}

Dry matter intake (DMI) of cows was significantly $(P<0.001)$ varied among treatments (Table 3$)$. Cows fed T3, maximum FSF included, had highest DMI followed by T2. The variation might be resulted from the difference in NDF content of FSF and OG as indicated in Table 2. It means increase in levels of FSF in the diet of cows' increased voluntary intake of feeds. From the laboratory analysis result, it is observed that NDF of FSF $(32.7 \%)$ is lower than that of OG (42.8\%). NDF content is negatively correlated with feed intake of animals (Arelovich et al., 2008). Accordingly, high NDF in the diets delay passage rate of digesta which leads to gut fill (Allison, 1985). The gut fill in ruminants in turn leads to reduction in voluntary feed intake of ruminants (Allison, 1985). In contrary to this, low NDF or higher soluble carbon enhances 


\section{Diribe Kumsa et al.,}

microbial populations which increase degradation of the mats in the rumen. Fast degradation of mats leads to increased passage rate which in turn reduce gut fill thereby increasing feed intake of the animals.

Crude protein intake $(\mathrm{CPI})$ was not significantly differed ( $P>0.05)$ among the treatments (Table3). This might be attributed to an iso-nitrogenous level formulated $\mathrm{CP}$ in the experimental diets. Otherwise any difference among the treatment might appeared from the difference in content of OG and FSF. Neutral detergent fiber (NDF) and acid detergent fiber (ADF) intakes were also significantly different $(P<0.001)$ among treatment groups. Cows fed on T1 and T2 had the lowest NDF intake which obviously follow similar trend with its DMI. This lower feed intake, in turn associated with the high proportions of OG in these treatments and OG had higher NDF content than that of FSF (Table2). The TOMI followed the logical trend of the TDMI of the cows.

Table 3: Mean dry matter and nutrient intakes $(\mathrm{kg}$ DM/day) of Horro cows fed different treatment diets

\begin{tabular}{cccccc}
\hline Variable & TDMI & TCPI & TNDFI & TADFI & TOMI \\
\hline T1 & $5.01^{\mathrm{c}}$ & 0.76 & $3.48^{\mathrm{c}}$ & $1.86^{\mathrm{c}}$ & $3.98^{\mathrm{c}}$ \\
T2 & $5.88^{\mathrm{b}}$ & 0.77 & $4.09^{\mathrm{b}}$ & $2.04^{\mathrm{b}}$ & $4.59^{\mathrm{b}}$ \\
T3 & $6.91^{\mathrm{a}}$ & 0.77 & $5.14^{\mathrm{a}}$ & $2.51^{\mathrm{a}}$ & $5.65^{\mathrm{a}}$ \\
\hline $\begin{array}{c}\text { Overall } \\
\text { mean }\end{array}$ & 5.93 & 0.76 & 4.24 & 2.13 & 4.74 \\
\hline SEM & $\mathbf{0 . 1 9}$ & $\mathbf{0 . 0 1}$ & $\mathbf{0 . 0 3}$ & $\mathbf{0 . 2 0}$ & $\mathbf{0 . 0 7}$ \\
CV & $\mathbf{3 . 1 8}$ & $\mathbf{0 . 7 2}$ & $\mathbf{2 . 7 4}$ & $\mathbf{7 . 5 8}$ & $\mathbf{1 . 4 9}$ \\
$\mathbf{P}$ & $\mathbf{0 . 0 0 0 1}$ & $\mathbf{0 . 7 9}$ & $\mathbf{0 . 0 0 0 1}$ & $\mathbf{0 . 0 0 0 1}$ & $\mathbf{0 . 0 0 0 1}$
\end{tabular}

${ }^{\text {abc }}$ Means with different superscripts within columns are significantly different at ${ }^{*}=(P<0.05) ;{ }^{* *}=(P<0.01) ;{ }^{* * *}=(P<0.001) ; N S=$ not significant at $(P<0.05) ;$ TDMI $=$ total dry matter intake; TCPI = total crude protein intake; TNDFI = total neutral detergent fiber intake TADFI = total acid detergent fiber intake; TOMI= total organic matte intake; $\mathrm{T} 1=\mathrm{RGH}$ ad libtum $+1.7 \mathrm{~kg} \mathrm{OG}+0.8 \mathrm{NSC} ; \mathrm{T} 2=\mathrm{RGH}$ ad libtum + 0.56kg NSC + 0.97kg FSF + 0.97kg OG; T3 = RGH ad libtum $+0.8 \mathrm{~kg} \mathrm{NSC}+1.7 \mathrm{~kg} \mathrm{FSF}$

\section{Milk Yield and Chemical Composition}

The milk yield and composition of Horro cows fed different proportions of FSF and OG mixed diets was given in Table 4. Increased levels of FSF in the diet significantly $(P<0.001)$ increased milk yield in Horro cows. This means milk yield from cows supplemented with T3 was highest among the other dietary treatments. This could be due to the soluble forms of nutrients such as total sugars (starch plus simple sugars) contained in FSF than OG. Because increased soluble forms of carbohydrate increased feed intake (Table 3 ) which in turn
Sci. Technol. Arts Res. J., Jan-March 2016, 5(1): 39-45

increases milk yield of cows (Mosavi et al., 2012). The overall mean milk yield observed in the current study $(2.96 \pm 0.46 \mathrm{~kg} / \mathrm{day})$, was higher than the previous report for Horro cows (1.65kg/day) by Ayantu (2012). The difference might be due to the current feed effect, both supplements and basal diets, in the area. This finding confirms the fact that supplemented cows produced significantly more milk than those grazed on natural pasture alone (Adebabay et al., 2009).

All the analyzed milk compositions were significantly differed $(P<0.05)$ among treatment groups (Table4), however, any proportion of the two treatment diets, FSF and OG did not bring change in lactose content of the milk from Horro cows. The reason was not clear in view of more soluble nutrient content of FSF compared to OG. This was to mean that milk lactose synthesis would have been expected from the soluble components in FSF more than in OG.

The fat content was significantly higher $(P<0.001)$ for cows fed higher proportion of oats (T1 and T2) than cows received FSF (T3). The variation could be due to lower fiber content of FSF than OG. This happens when someone assume that the nutrients in the supplementary diets (FSF and OG)could dominate the basal diet of the cows, which is Rhodes grass in the current study. This implies that cows fed low roughage rations yield milk of lower fat content compared to cows fed higher proportion of roughage diet. Given the current result observed for fat content of milk from the cows', the role of soluble carbons in FSF in proliferating rumen microbes, so that the degradation of fiber in Rhodes hay basal diet was not effective in this particular study.

The CP content was significantly different $(P<0.05)$ among the treatments. Milk from cows supplemented with T3, despite iso-nitrogenous supplementation, had the highest $(p<0.05)$ protein content than milk from cows fed on T1 and T2 diets. This could be due to microbial origin protein source supported by soluble carbon from FSF. The total solid (TS), solid-not-fat (SNF) and ash contents of milk showed significant difference among treatments groups and followed the trend of $\mathrm{CP}$ in the milk of the cows. The high ash content of milk from cows consumed highest level of FSF in the diet might be from soil contaminated FSF during collection (dropped on the ground during collection). It is believed that the SNF content can fall if the cow fed a low energy diet (O'Connor 1994).

Table 4: Mean milk composition (\%) of Horro cows fed different proportions of FSF and OG diets

\begin{tabular}{|c|c|c|c|c|c|c|c|}
\hline \multirow[t]{2}{*}{ Treatments } & \multicolumn{7}{|c|}{ Milk Chemical Composition (\%) } \\
\hline & $\begin{array}{l}\text { Milk Yield } \\
\text { (Kg/day) }\end{array}$ & CP & Fat & TS & SNF & Ash & Lactose \\
\hline T1 & $2.53^{b}$ & $2.77^{b}$ & $3.77^{a}$ & $12.17^{\mathrm{b}}$ & $8.40^{c}$ & $0.63^{b}$ & 5.00 \\
\hline $\mathrm{T} 2$ & $2.89^{b}$ & $2.96^{\mathrm{ab}}$ & $3.20^{\mathrm{ab}}$ & $12.32^{\mathrm{b}}$ & $9.12^{\mathrm{b}}$ & $0.65^{\mathrm{ab}}$ & 5.51 \\
\hline T3 & $3.45^{a}$ & $3.22^{\mathrm{a}}$ & $3.00^{b}$ & $12.52^{\mathrm{a}}$ & $9.52^{\mathrm{a}}$ & $0.72^{\mathrm{a}}$ & 5.58 \\
\hline Overall Mean & 2.96 & 2.98 & 3.33 & 12.34 & 9.02 & 0.67 & 5.36 \\
\hline SEM & 0.46 & 0.26 & 0.16 & 0.11 & 0.15 & 0.02 & 0.27 \\
\hline CV & 8.67 & 8.69 & 4.85 & 0.87 & 1.67 & 3.54 & 5.07 \\
\hline $\mathbf{P}$ & 0.0022 & 0.0106 & 0.0002 & 0.0038 & 0.0001 & 0.0218 & 0.1230 \\
\hline
\end{tabular}




\section{Diribe Kumsa et al.,}

\section{Partial Budget Analysis}

The results for partial budget analysis of feeding different proportion of FSF with oats grain was given in Table 5. The gross financial margin or total return obtained in this trial was 5132.4, 5322.275, and 6156.75 ETB/cow/45days from cow fed T1, T2, and T3 diets, respectively. T1 has the lowest net return (4304.4 ETB) among the other treatments, T2 and T3 with values 4902.15 ETB and 5443.5 ETB, respectively. The highest net return was obtained in $T_{3}$, for cows supplemented with maximum levels of FSF $(1.7 \mathrm{~kg})$. The higher net income and MRR in T3 might be due to the lower cost of FSF (2.5 $\mathrm{ETB} / \mathrm{kg}$ ) compared to the cost of oat grains. In addition, the total return, net return and marginal rate of return were based not only on the lower cost of FSF, but also the higher record for milk yield from cows fed T3 diets. The
Sci. Technol. Arts Res. J., Jan-March 2016, 5(1): 39-45

change of net income obtained in T2 and T3 were 597.75 and 541.35 ETB, respectively with the corresponding marginal rate of return of 6.11 and 32.08 .

Thus, the result of this study indicated that supplementation of Ficus sur fruit with Noug seed cake to Rhodes hay basal diets was potentially profitable and economically feasible than those supplemented with Oat grain. Marginal rate of return measure the increase in net income $(\Delta \mathrm{NI})$ and the effect of additional investment in a new technology on additional expenditures ( $\triangle T V C)$. Thus, among the treatments T3 which has more net return also has more potential for profitability. Therefore, in this study, maximum levels of FSF $(1.7 \mathrm{~kg})$ or T3 diets, with 32.08 MRR would be recommended as best dietary treatment for profitable milk production.

Table 5: Partial budget analysis of Horro cows fed Rhodes grass hay supplemented with different proportions of FSF and OG diets

\begin{tabular}{|c|c|c|c|c|}
\hline & & \multicolumn{2}{|c|}{ Treatments } & Price of feeds and milk/kg \\
\hline $\begin{array}{c}\text { Total concentrate intake } \\
\text { (kg/cow/45days ) }\end{array}$ & T1 & T2 & T3 & \\
\hline NSC & 36 & 25.2 & 36 & \\
\hline FSF & 0 & 43.65 & 76.5 & \\
\hline OG & 76.5 & 43.65 & 0 & \\
\hline $\mathrm{RGH}$ & 135 & 135 & 135 ( 9 bales) & \\
\hline \multicolumn{5}{|l|}{ Feed cost } \\
\hline \multicolumn{5}{|l|}{ Total concentrate cost (ETB) } \\
\hline NSC & 252 & 176.4 & 252 & $1 \mathrm{~kg}=7 \mathrm{birr}$ \\
\hline FSF & 0 & 109.125 & 191.25 & $1 \mathrm{~kg}=2.5 \mathrm{birr}$ \\
\hline OG & 306 & 174.6 & 0 & $1 \mathrm{~kg}=4 \mathrm{birr}$ \\
\hline $\mathrm{RGH}$ & 270 & 270 & 270 & $1 \mathrm{bell}=15 \mathrm{~kg}=30 \mathrm{birr}$ \\
\hline Total Variable costs & 828 & 730.125 & 713.25 & \\
\hline Total milk yield/cow/45days (L) & 496.7 & 530.2 & 572.5 & \\
\hline Milk Selling price (ETB) & 5960.4 & 6362.4 & 6870 & $1 \mathrm{~L}=12 \mathrm{birr}$ \\
\hline Total return (ETB) & 5132.4 & 5632.275 & 6156.75 & \\
\hline Net return (ETB) & 4304.4 & 4902.15 & 5443.5 & \\
\hline$\Delta \mathrm{TVC}$ & - & -97.875 & -16.875 & \\
\hline$\Delta \mathrm{TR}$ & - & 499.875 & 524.475 & \\
\hline$\Delta \mathrm{NI}$ & - & 597.75 & 541.35 & \\
\hline MRR & - & 6.11 & 32.08 & \\
\hline
\end{tabular}

\section{CONCLUSIONS}

Supplementation of highest proportion of FSF $(1.7 \mathrm{~kg} / \mathrm{day})$ in the ration of Horro cows kept on Rhodes grass hay basal diet resulted in increased milk production and composition and returned the highest income. Due to high cost of agro industrial by products and increasing competition with human being for cereals grains, it is economically advantageous to use Ficus sur fruits as supplement to improve milk productivity of Horro cows. Since the FSF was nutritionally promising, further study will be done on how to determine the fruit yields of Ficus sur trees.

\section{REFERENCES}

Adebabay, K., Firew T., Zeleke, M. and Azage, T. (2009). OnFarm Evaluation of the Effect of Concentrate and Urea Treated Wheat Straw Supplementation on Milk Yield and Milk Composition of Local Cows. In: Zelalem Yilma and Aynalem Haile (Eds). Proceedings of the 17th Annual conference of the Ethiopian Society of Animal Production
(ESAP) held in Addis Ababa, Ethiopia, September 24 to 26, 2009. ESAP, Addis Ababa.

Adugna, T. (2007). Feed resources for producing export quality meat and livestock in Ethiopia. Examples from Selected Woredas in Oromia and SNNP Regional States; Ethiopian sanitory and Phytosanitary standards livestock and meat marketing program (SPS-SLMM). Addis Ababa, Ethiopia; p 52.

Adugna, T. (2008). Feed resources and feeding management :A manual for feedlot operators and development workers. SPS-LMM Program, Addis Ababa, Ethiopia.

Alemayehu, M. (2006). Country Pasture/Forage Resource Profiles. FAO, Ethiopia.

Allison, C.D. (1985). Factors Affecting Forage Intake by Range Ruminants: A Review. Journal of Range Management 38(4): 305-311

AOAC (Association of Official Analytical Chemist) (2000). Official methods of Analysis (Vol. II 17th Ed.) of AOAC 


\section{Diribe Kumsa et al.,}

International. Washington, DC, USA. Official methods 926.08,920.123,933.05,975.20 and 900.02.

Arelovich, H., M. Abney, C .S. Vizcarra, J. A., Galyean, P A S M. (2008) Effects of Dietary Neutral Detergent Fiber on Intakes of Dry Matter and Net Energy by Dairy and Beef Cattle: Analysis of Published Data. The Professional Animal Scientist 24: 375-383.

Ayantu, M., Tadelle D and Yoseph M. (2012). On farm characterization of Horro cattle breed production systems in western Oromia, Ethiopia. Livestock Research for Rural Development. 24: Article 100.

Azage, T., Berhanu G, Dirk H, Berhanu B and Yoseph M. (2013). Smallholder dairy production and marketing systems in Ethiopia: IPMS experiences and opportunities for market-oriented development. IPMS (Improving Productivity and Market Success) of Ethiopian Farmers Project Working Paper 31. Nairobi: ILRI.

Behnke, R. and Metaferia, F. (2011). The Contribution of Livestock to the Ethiopian Economy -Part II, IGAD Livestock Policy Initiative (LPI) Working Paper No. 02 -11, Retrieved on September 20, 2013.

Belay, D., Getachew, E., Tessema, Z. and Adugna, T. (2014). Comparison of Nutritive Value of Alfalfa, Rhodes Hay, Cynodon Pasture and Linseed Cake -Maize Mixture at Hawassa College of Agriculture, Ethiopia. Academic Journal of Nutrition 3(2): 19-21.

Belay, D., Yisehak, K., and Janssens ,G. .P J. (2012). Productive and reproductive performance of Zebu $X$ Holstein-Friesian crossbred dairy cows in Jimma town, Oromia, Ethiopia. Global Veterinaria, 8(1): 67-72.

Bezuayehu,T. (2006). People and Dams: Environmental and socio- economic changes induced by a reservoir in Finca'a water shade Western Ethiopia. PhD Dissertation, Wagneningen University, the Netherlands.

CSA (Central Statistical Authority). (2013). Agricultural Sample Survey. Volume II: Report on Livestock and livestock characteristics (Private peasant holdings). Statistical Bulletin 570, CSA, Addis Ababa, Ethiopia.

Demissu, H. Fekadu, B. and Gemeda, D. (2015). Productivity of Horro cattle and their F1 Jersey Crosses. LAP LAMBERT Academic Publishing.

Diriba, D. (2014). Evaluation of Ficus sur fruits as feed and food. Doctoral dissertation, Haramaya University, Haramaya, Ethiopia.

Fentie, B. and Solomon, M. (2008). Feed Utilization and Live Wight change of Farta sheep Supplemented with noug seed (Guizotia abyssinica) cake, wheat bran and their mixtures. Tropical Animal Health and Production. 40: 597-606.

Foley, J., Buckley, J. and Murphy, M. F. (1974). Commercial testing and product control in the dairy industry. University College Cork.

ILCA (International Livestock Center for Africa). (1992). ILCA Annual Report and Program Highlights. ILCA, Addis Ababa, Ethiopia.

Makhdoom, A. (2012). Nutritive Value of Rhodes Grass (Chloris gayana). Riphah College of Veterinary Sciences, Lahore. Training Pakistan Private Limitted. pp01-12.

McDonald, P., Edwards, R.A., Greenhalgh, J.F.D., Morgan, C.A. and Longman. (1995). Animal Nutrition. Fifth Edition. 607p
Sci. Technol. Arts Res. J., Jan-March 2016, 5(1): 39-45

Mesfin, D., Seyoum, B., Aemiro, K., Getu, K., Kedir, N. (2009). On-farm evaluating of lactating crossbred (Bos Taurus $x$ Bos indicus ) dairy cows fed basal diet of urea treated teff (Eragrostis teff) straw supplenmented with escape of protein source during dry season in croplivestock production system of north Shoa, Ethiopia. Livestock Research for Rural Development 21: Article \#61.

Mosavi, G.H.R., Fatahnia, F., Alamouti, M.H.R., Mehrabi, A.A. and Kohi D. H. (2012). Effect of dietary starch source on milk production and composition of lactating Holstein cows; South African Journal of Animal Science, 42 (3): 201-209

Mulat, A. (2006). Effects of supplementing different protein sources on feed intake and live weight gain of local sheep fed on finger millet (Eleucine coracana) straw basal diet. MSc Thesis, Haramaya University, Haramaya, Ethiopia. 67p.

Mulugeta, A. and Belayeneh ,A. (2013). Reproductive and lactation performances of dairy cows in Chacha Town and nearby selected kebeles, North Shoa Zone, Amhara Region, Ethiopia. World Journal of Agricultural Sciences 1(1): 08-017.

O'Connor, C. B. (1994). Rural dairy technology. ILRI training manual No. 1. International Livestock Research Institute (ILRI), Addis Ababa, Ethiopia. 133p.

O'Mahoney, F. (1988). Rural dairy technology-Experiences in Ethiopia. ILCA Manual No. 4. Dairy Technology Unit. ILCA, Addis Ababa, Ethiopia. p 64

Pandey, G. S. and Voskuil, G. C. J. (2011). Manual on milk safety, quality and hygiene. GART.

Richardson, G.H. (1985). Standard Methods for the Examination of Dairy Products. Fifteenth Edition. American Public Health Association. Washington, D. C, pp. 168-196.

SAS (Statistical Analysis System) (2009). The Little SAS ${ }^{8}$ Book: A Primer, Fourth Edition, version 9.1.3. Statistical analysis system institute Inc., NC. USA.

Staton. T.L. (2014). Feed composition for cattle and sheep. A division of state of engagement, Colorado University

Smith E., Benbrook C. and Davis D.R. (2012). With the Grain: A closer look at the nutrient quality of grain, grain-based products, and the role of organic agriculture; The Organic Center; www.organic-center.org

Upton, M.1979. Farm Management in Africa: The Principle of Production and Planning. Oxford University Press, Great Britain, pp.282-298.

VanSoest, P.J. (1994). Nutritional Ecology of Ruminant. Second edition. Cornell University press. London. 476p.

VanSoest, P. J. and Robertson, J. B. (1985). Analysis of Forages and Fibrous Feeds. Laboratory manual for Animal Science 613, Cornell University, Ithaca. New York, 202 P.

Vanden, B.J.C.T. (1988). Dairy Technology in the tropic and subtropics. Center for Agricultural Publishing and Documentation (Pudoc). Wagneningen, the Netherlands, 290p.

Wondwosen, A. (2008). Effect of supplementing hay from natural pasture with oil seed cakes on feed intake, digestibility and live weight change of Sidama goats. MSc Thesis, Haramaya University. Haramaya, Ethiopia. 22p. 